\title{
Some reflections on the modelling of biogenic emissions of monoterpenes in the boreal zone
}

\author{
K. M. Granström \\ Department of Energy, Environmental and Building Technology, \\ Karlstad University, Sweden
}

\begin{abstract}
Trees emit volatile organic compounds, mostly monoterpenes and isoprene. These biogenic substances are the dominant volatile organic compounds in air in forested regions. They contribute to the formation of thopospheric ozone and other photochemical oxidants if mixed with polluted air from urban areas. Increased ozone levels hamper photosynthesis and thus have a negative impact on the growth of forests and crops. Terpene flux estimations are needed for models of atmospheric chemistry and for carbon budgets. Several models of natural terpene emission have been constructed, both in a global scale and for various regions. Ideally, a model of natural terpene emissions should show the terpene flux at different times of day and year, at different weather conditions, and for different ecosystems. Its resolution should be sufficient to show short emission peaks. It should also be able to accommodate extreme events like pest outbreaks and serious storms, especially since those are expected to become more common due to global warming. An examination of the scientific literature on monoterpene content in trees and emission fluxes for the dominant boreal forest tree species shows that models aiming to predict terpene fluxes from natural sources over time should include the factors temperature and light intensity, and possibly also take into account the seasonal variation of terpene levels in trees. As wood tissue damage increases emissions, a base level of herbivory and insect predation should be estimated and included. When identification of high concentrations is important, models should have sufficient resolution to capture the emission peaks found, for example, at bud break. The temperature dependence is shown to vary sufficiently between different tree species to motivate using specific values for the ecosystems examined.
\end{abstract}

Keywords: biogenic, volatile, terpene, model, forest, boreal, spruce, pine, birch. 


\section{Introduction}

Many plants emit biogenic volatile organic compounds (BVOC), mostly monoterpenes, isoprene and volatile carbonyl compounds. The boreal vegetation zone is heavily forested, mostly with pine and spruce. Birches dominate amongst the deciduous trees. In regions dominated by conifers or non-isoprene emitting deciduous tree species, monoterpenes may dominate BVOC emissions (Rinne et al. [1]). Estimates of BVOC emissions are important inputs for models of atmospheric chemistry (Geron et al. [2]). VOC from forests contribute to the formation of ozone and other photochemical oxidants if mixed with polluted air from urban areas. Increased ozone levels hamper photosynthesis and thus have a negative impact on forest and crops. The emissions of BVOC are also important when calculating carbon budgets. The aim of this paper is to elucidate which factors should be included in models of emissions of biogenic volatiles in the boreal zone. The species examined are norway spruce (lat. Picea abies), scots pine (lat. Pinus silvestris), and birches (lat. Betula pendula, Betula pubescens).

\subsection{Emission models}

Several models of BVOC emission flux have been constructed, both in a global scale and for various regions. According to a frequently used model created by Guenther et al. $[3,4]$ the emission flux is given by the equation

$$
F=D \varepsilon \gamma,
$$

where $F$ is emission flux $\left(\mu \mathrm{gC} \mathrm{m} \mathrm{m}^{-2} \mathrm{~h}^{-1}\right), D$ is foliar density $\left(\mathrm{gdw} \mathrm{m}^{-2}\right), \varepsilon$ is an ecosystem dependent emission factor $\left(\mu \mathrm{gC} \mathrm{gdw}^{-1} \mathrm{~h}^{-1}\right)$, and $\gamma$ is an activity factor dependent on temperature calculated as

$$
\gamma=\exp \left[\beta\left(T-T_{s}\right)\right]
$$

where $\beta$ is an empirical coefficient $\left({ }^{\circ} \mathrm{C}^{-1}\right), T$ is leaf temperature and $T_{\mathrm{s}}$ is a standard temperature of $30^{\circ} \mathrm{C}$. Guenther et al. [3] cites estimates of $\beta$ ranging from 0.057 to $0.144^{\circ} \mathrm{C}^{-1}$ with half of the values within $0.090 \pm 0.015$, and suggest a best estimate of $0.09{ }^{\circ} \mathrm{C}^{-1}$ for all plants and monoterpenes. Seasonal and spatial changes in species composition and foliar density are further developed in Guenther [5].

In a model of global emissions by Guenther et al. [4], temporal variations are driven by monthly estimates of biomass and temperature and, for modelling of isoprene fluxes, by hourly light estimates. A model for terpene emissions from European boreal forest (Lindfors et al. [6]), based on the Guenther emission algorithms, takes into account the dependence of light intensity and the latitudinal variation of the biomass of conifers and the seasonal variability of the biomass of boreal deciduous trees.

\section{Factors affecting emissions}

There is a large natural variation in the extractive content of plants, and thus variations in the amount and type of emissions. There are also many external 
factors affecting biogenic terpene emissions, such as temperature, light intensity, the season (the plants' growth stadium), damage (herbivory, insects, fungi or touch), rain and air pollution.

\subsection{Temperature}

Monoterpenes are stored in special cells in the needles of conifers and leaves of deciduous trees and are emitted primarily through volatilisation. Emission rates are strongly dependent on the temperature of the leaf surface (Guenther et al. [3]). The infra-red radiation of a scots pine stand has a good correlation with monoterpene emissions from the canopy (Hakola et al. [7]).

\subsection{Light}

Marked diurnal variations with a maximum around noon have been observed for boreal coniferous forest in Sweden (Johansson and Janson [8]), Finland, (Spanke et al. [9]), and for a mixed Canadian deciduous forest (Fuentes et al. [10]). After normalisation to temperature, emission rates from scots pine and norway spruce still vary diurnally with a maximum at midday (Janson [11]), which implies an effect of light intensity. Likely, terpenes are not only released from storage pools but also released directly after synthesis. The terpene precursor isoprene is released immediately and its emission rate is strongly dependent on both temperature and light intensity. The storage pool emissions a percentage of total monoterpene emission potentials have been reported as $63 \%$ for scots pine and $64 \%$ for norway spruce in southern Germany (Steinbrecher et al. [12]).

\subsection{Season (the plants' growth stadium)}

The terpene concentration in wood is low during winter, increases rapidly in spring, reaches a maximum during summer, and drops off to the base level in autumn. The seasonal cycle in terpene concentration can be observed even in the absence of herbivory, probably due to increased attacks by herbivores in the evolutionary past (Lerdau et al. [13]). At bud break, the emission rates of monoterpenes to air increase sharply both for conifers (Lerdau et al. [14]) and for deciduous trees (Fuentes et al. [10]). Terpene emissions then decrease after the first few days or weeks after bud break (Hakola et al. [15]).

\subsection{Damage}

Monoterpene production is induced when the plant is attacked, for instance by herbivores or fungi or insects. Spruces rely on biosynthesis at the affected area when damage occurs, while pines have high level monoterpene resin transported via interconnected resin canals appearing at wound sites within seconds after an injury occurs (Lewinsohn et al. [16]). Calculated whole-canopy fluxes imply that a ponderosa pine forest with $10 \%$ damaged foliage will emit 2 times more monoterpenes, and $25 \%$ damage 3.6 times more than undamaged forest, while the same damage to a douglas-fir forest gives 1.6 times and 2.5 times more 
monoterpenes, respectively (Litvak et al. [17]). The increased emissions from the low level of grazing (10\% damage) is sufficient to increase local tropospheric ozone production (Litvak et al. [17]). Debudding a scops pine branch increased its monoterpene emissions for about a week (Hakola et al. [18]). Touch is suspected to cause higher monoterpene emission rates (Guenther et al. [19]). This makes it very important to avoid rough handling of vegetation during enclosure experiments.

\subsection{Rain}

Emissions of monoterpenes increase temporarily during and after heavy rain (Janson [11]).

\subsection{Air pollution}

Considering that monoterpenes protect plants against ozone damage (which works in the absence of nitrogen oxides) monoterpene emissions ought to increase with increasing ozone concentration. Such a connection has been found for pine, while the results for spruce are ambiguous. Long-term ozone treatment of scots pine led to increased emissions of monoterpenes (Heiden et al. [20]). Traffic pollution increase monoterpene emission rate from norway spruce (Juttner [21]). When norway spruce in open-top chambers was exposed to air with or without added ozone, no significant difference in terpene emissions to air was found (Lindskog and Potter [22]).

\section{Natural emissions of terpenes}

\subsection{Monoterpene flux estimates}

Norway spruce has relatively stable emissions from the onset in late May until October (table 1). Norway spruce emit more terpenes than scots pine does (table 1). The $\mathrm{E}_{30}$-value assumed in the model in Lindfors et al. [6], $1.5 \mu \mathrm{g} \mathrm{gdw}^{-1}$, is a reasonable approximation for scots pine, but likely to lead to underestimations of emissions from norway spruce.

Both silver birch and downy birch emitted terpenes at bud break in May, after which the emission rate declined and was low while the leaves grew. When the leaves had reached their full size, the emission rate increased and remained high during the rest of the growing season (Hakola et al. [7,15]). In the model by Lindfors et al. [6], birch has an $\mathrm{E}_{30}$-value of 0.64 in early summer and 5.6 in late summer.

\subsection{Monoterpene ambient measurements}

Ambient concentrations have been found to be larger at night (Petersson [25], Janson [26]). This despite that the terpene emissions are higher during the day (Rinne et al. [1]). The higher concentrations at night have been attributed to lower dispersion. In addition, ozone concentrations are higher in the daylight hours. 
Table 1: $\quad$ Monoterpene fluxes $\left(\mu \mathrm{g} \mathrm{gdw}^{-1} \mathrm{~h}^{-1}\right)$ for boreal trees; where \pm is given it denotes 1 standard deviation; values are normalised using $\beta=0.09$.

\begin{tabular}{|c|c|c|c|c|c|}
\hline \multirow{3}{*}{$\begin{array}{l}\text { Tree } \\
\text { species }\end{array}$} & \multirow{2}{*}{$\begin{array}{l}\text { Month } \\
\text { (Date) } \\
\text { May (5) }\end{array}$} & \multicolumn{3}{|c|}{$\begin{array}{l}\mathrm{E} \quad\left(\mu \mathrm{g} \mathrm{E}_{30} \quad(\mu \mathrm{g} \text { Location }\right. \\
\left.\left.\mathrm{gdw}^{-1} \mathrm{~h}^{-1}\right) \mathrm{gdw}^{-1} \mathrm{~h}^{-1}\right)\end{array}$} & \multirow{2}{*}{$\begin{array}{l}\text { Ref. } \\
\text { J93 } \\
\end{array}$} \\
\hline & & 0.48 & 0.73 & Sweden $\left(60^{\circ} \mathrm{N}, 16^{\circ} \mathrm{E}\right)$ & \\
\hline & May (29) & 0.45 & 4.4 & Sweden $\left(60^{\circ} \mathrm{N}, 16^{\circ} \mathrm{E}\right)$ & J93 \\
\hline & June $(2,4)$ & 1.8 & $2.3 \pm 1.1$ & Sweden $\left(60^{\circ} \mathrm{N} 17^{\circ} \mathrm{E}\right)$ & J99 \\
\hline & June (12) & 0.20 & 2.1 & Sweden $\left(60^{\circ} \mathrm{N}, 16^{\circ} \mathrm{E}\right)$ & J93 \\
\hline & June (20) & 3.8 & $5.2 \pm 0.5$ & Sweden $\left(60^{\circ} \mathrm{N} 17^{\circ} \mathrm{E}\right)$ & J99 \\
\hline & July $(8,9)$ & 2.4 & $2.3 \pm 0.3$ & Sweden $\left(60^{\circ} \mathrm{N} 17^{\circ} \mathrm{E}\right)$ & J99 \\
\hline & July (31) & 0.12 & 4.3 & Sweden $\left(60^{\circ} \mathrm{N}, 16^{\circ} \mathrm{E}\right)$ & J93 \\
\hline & Aug (21) & 0.57 & 3.4 & Sweden $\left(60^{\circ} \mathrm{N}, 16^{\circ} \mathrm{E}\right)$ & J93 \\
\hline & Sep (20) & 2.0 & $8.3 \pm 6.1$ & Sweden $\left(60^{\circ} \mathrm{N} 17^{\circ} \mathrm{E}\right)$ & J99 \\
\hline & Oct (5) & 0.61 & 31 & Sweden $\left(60^{\circ} \mathrm{N}, 16^{\circ} \mathrm{E}\right)$ & J93 \\
\hline \multirow{17}{*}{$\begin{array}{l}\text { Scots } \\
\text { pine }\end{array}$} & May (3) & 1.3 & 1.0 & Sweden $\left(60^{\circ} \mathrm{N}, 16^{\circ} \mathrm{E}\right)$ & J93 \\
\hline & May $(29,30)$ & 0.8 & 0.67 & Sweden $\left(60^{\circ} \mathrm{N}, 16^{\circ} \mathrm{E}\right)$ & J93 \\
\hline & June (20) & 0.22 & 2.6 & Sweden $\left(60^{\circ} \mathrm{N}, 16^{\circ} \mathrm{E}\right)$ & J93 \\
\hline & June (22) & 0.46 & 1.3 & Sweden $\left(60^{\circ} \mathrm{N}, 16^{\circ} \mathrm{E}\right)$ & J93 \\
\hline & June (26) & 0.38 & 3.7 & Sweden $\left(60^{\circ} \mathrm{N}, 16^{\circ} \mathrm{E}\right)$ & J93 \\
\hline & June (27) & 0.32 & 1.1 & Sweden $\left(60^{\circ} \mathrm{N}, 16^{\circ} \mathrm{E}\right)$ & J93 \\
\hline & July (12) & 0.28 & 2.7 & Sweden $\left(60^{\circ} \mathrm{N}, 16^{\circ} \mathrm{E}\right)$ & J93 \\
\hline & July (20) & 0.28 & 3.4 & Sweden $\left(60^{\circ} \mathrm{N}, 16^{\circ} \mathrm{E}\right)$ & $\mathrm{J} 93$ \\
\hline & July & - & 1.2 & Finland $\left(62^{\circ} \mathrm{N}, 30^{\circ} \mathrm{E}\right)$ & R00 \\
\hline & Aug (18) & 2.0 & 1.1 & Sweden $\left(60^{\circ} \mathrm{N} 17^{\circ} \mathrm{E}\right)$ & J99 \\
\hline & Aug (19) & 0.54 & 1.9 & Sweden $\left(60^{\circ} \mathrm{N} 17^{\circ} \mathrm{E}\right)$ & J99 \\
\hline & Aug (21) & 0.1 & 0.77 & Sweden $\left(60^{\circ} \mathrm{N}, 16^{\circ} \mathrm{E}\right)$ & J93 \\
\hline & Aug (30) & 0.074 & 1.3 & Sweden $\left(60^{\circ} \mathrm{N}, 16^{\circ} \mathrm{E}\right)$ & $\mathrm{J} 93$ \\
\hline & Aug (31) & 0.11 & 0.86 & Sweden $\left(60^{\circ} \mathrm{N}, 16^{\circ} \mathrm{E}\right)$ & $\mathrm{J} 93$ \\
\hline & Sep (6) & 0.34 & 2.7 & Sweden $\left(60^{\circ} \mathrm{N} 17^{\circ} \mathrm{E}\right)$ & J99 \\
\hline & Sep (7) & 0.39 & 7.5 & Sweden $\left(60^{\circ} \mathrm{N} 17^{\circ} \mathrm{E}\right)$ & J99 \\
\hline & Oct (5) & 0.58 & 45 & Sweden $\left(60^{\circ} \mathrm{N}, 16^{\circ} \mathrm{E}\right)$ & $\mathrm{J} 93$ \\
\hline \multirow{5}{*}{$\begin{array}{l}\text { Silver } \\
\text { birch }\end{array}$} & May (24) & 5.6 & 14 & Finland $\left(60^{\circ} \mathrm{N} 25^{\circ} \mathrm{E}\right)$ & H98 \\
\hline & June (12) & 0.4 & 0.5 & Finland $\left(60^{\circ} \mathrm{N} 25^{\circ} \mathrm{E}\right)$ & $\mathrm{H} 98$ \\
\hline & June (25) & -0.2 & -6 & Finland $\left(60^{\circ} \mathrm{N} 25^{\circ} \mathrm{E}\right)$ & H98 \\
\hline & Aug (14-22) & $6-12$ & $6-12$ & Finland $\left(60^{\circ} \mathrm{N} 25^{\circ} \mathrm{E}\right)$ & H98 \\
\hline & $\operatorname{Sep}(3,6)$ & $0.05-1$ & $1-5$ & Finland $\left(60^{\circ} \mathrm{N} 25^{\circ} \mathrm{E}\right)$ & H98 \\
\hline \multirow{2}{*}{$\begin{array}{l}\text { Downy } \\
\text { birch }\end{array}$} & Early summer & & 0.76 & Finland $\left(60^{\circ} \mathrm{N} 25^{\circ} \mathrm{E}\right)$ & $\mathrm{H} 99$ \\
\hline & Late summer & & 6.08 & Finland $\left(60^{\circ} \mathrm{N} 25^{\circ} \mathrm{E}\right)$ & H99 \\
\hline
\end{tabular}

J93 Janson [11]; J99 Janson et al. [23]; R00 Rinne et al. [24]; H98 Hakola et al. [15]; H99 Hakola et al. [7]. 
The ambient monoterpene concentration varies over the year, with detectable concentrations beginning at bud break and a maximum at mid-summer. This was found by Janson [26] for scots pine, and for a deciduous forest by Fuentes et al. [10].

\section{Implications for emission modelling}

The monoterpene fluxes show considerable variations over time. Terpene emissions depend on temperature, but the diurnal variations are also an effect of variable light intensity. Bud break is an important emission period for both deciduous trees and conifers. To use monthly estimates of biomass and temperature would likely not reflect reality for zones with a variable climate, like the boreal zone where there is strong seasonal variability of temperature and light and also highly variable deciduous foliage density over the year. To use global averages for modelling of emissions in regions can not be expected to give accurate results, as the emission factors differ between regions.

Considering the effect of grazing, it is not surprising that forestry has a considerable impact on terpene emissions (Strömvall and Petersson [27]). This is outside the scope for models of natural BVOC emissions, but very important when the aim is to include both natural and anthropogenic emissions. For models of natural emissions, a base level of herbivory and pests could be included. This is probably not the case today, as branch enclosure experiments have been done on mostly visibly healthy branches, which does not reflect the emissions from damaged vegetation. While the healing of damages by oxidized resins is reasonably fast, the damage from grazing of young conifers is both considerable and frequent. If forest harvesting is included in emission models, the seasonal variation of terpene content in wood could be of interest.

The model by Lindfors et al. [6] includes both temperature and light intensity and the latitudinal variation of the biomass of conifers and the seasonal variability of the biomass of boreal deciduous trees. However, the monoterpene emission rates ( $\varepsilon$ in equation 1 ) are too schematic. While the model stretches from April to October, there are only two time periods for emission rates - early summer and late summer. This does not fully capture the seasonal variation, and the low $E_{30}$-value assigned to birch in early summer does not correspond to the high emissions during bud break found for Silver birch. Also, all conifers are assumed to have a normalised emission factor of $1.5 \mu \mathrm{g} \mathrm{gdw}^{-1} \mathrm{~h}^{-1}$ during both periods, which does not take into account the difference between Norway spruce and Scots pine.

The exponential increase in emissions with increased temperature in the commonly used equation

$$
E=E_{30} \exp \left[\beta\left(T-30^{\circ} \mathrm{C}\right)\right],
$$

where $E_{30}$ is the monoterpene emission normalised to $30^{\circ} \mathrm{C}$ (Guenther et al. [3]) and $\beta$ and $T$ are defined as in equation 2, is supported empirically but does not convey the full complexity of the temperature dependence of monoterpene emission of plants. For example, the increase of emissions with temperature is sometimes not observed during very hot and dry weather (Schade et al. [28]). 
Several estimations of the coefficient $\beta$ in equation 1 and 3 have been made for trees in the northern boreal region (table 2). A tentative latitudinal correlation can be seen. $\beta$-values have been reported as 0.24 for birch (Hakola et al. [15]). Although the value for birch is higher than those reported for spruce and pine, it is not sufficiently high to explain the high $\beta$-value found for a mixed forest by Rinne et al. [1]. The higher temperature dependence for deciduous trees is likely due to their high accumulation of monoterpenes in the cuticle, while conifer cuticles contains less monoterpenes (Schmid et al. [29]).

Table 2: $\quad$ Temperature dependence of the emission of monoterpenes from trees, as values of $\beta$ in the Guenther algorithm $\mathrm{E}=\mathrm{E}_{30} \exp [\beta(\mathrm{T}$ $\left.\left.30^{\circ} \mathrm{C}\right)\right]$.

\begin{tabular}{lllll}
\hline Location & $\begin{array}{l}\text { Norway } \\
\text { spruce }\end{array}$ & Scots pine & $\begin{array}{l}\text { Mixed } \\
\text { forest* }\end{array}$ & Ref. \\
\hline$\left(60^{\circ} \mathrm{N}, 16^{\circ} \mathrm{E}\right)$ & 0.07 & 0.07 & & Janson [11] \\
\hline$\left(60^{\circ} \mathrm{N} 17^{\circ} \mathrm{E}\right)$ & $0.065-0.097$ & $0.068-0.15$ & $\begin{array}{l}\text { Janson and de Serves } \\
{[30]}\end{array}$ \\
\hline$\left(62^{\circ} \mathrm{N}, 30^{\circ} \mathrm{E}\right)$ & & 0.15 & & Rinne et al. [24] \\
\hline$\left(68^{\circ} \mathrm{N}, 24^{\circ} \mathrm{E}\right)$ & & & $0.96-1.7$ & Rinne et al. [1] \\
\hline
\end{tabular}

*Spruce $56 \%$, birch $32 \%$, Pine $10 \%$ as dry leaf mass.

Most emission rate values are reported as normalised to $30^{\circ} \mathrm{C}$ using $\beta=0.09^{\circ} \mathrm{C}^{-1}$, as found by Guenther et al. [3]. A terpene flux that is $2.7 \mu \mathrm{gdw}^{-1}$ $\mathrm{h}^{-1}$ if normalised to $30^{\circ} \mathrm{C}$ using $\beta=0.15^{\circ} \mathrm{C}^{-1}$ will be $1.2 \mu \mathrm{g} \mathrm{gdw}^{-1} \mathrm{~h}^{-1}$ with a $\beta$ value of $0.09^{\circ} \mathrm{C}^{-1}$ (Rinne et al. [24]). These values differ by a factor of 2 . It is therefore important to use a locally correct value of $\beta$, and to recalculate reported values before they are used for modelling.

\section{Concluding remarks}

High quality data on emission factors is necessary for the modelling of canopy fluxes of terpenes. The terpene fluxes are needed in models of atmospheric chemistry and effects of photochemical oxidants, and also for carbon budgets. While biogenic terpenes are far from the only VOCs in air, they, together with isoprene, are dominant in forested regions. To be really useful a model should give the terpene and isoprene contribution to ozone formation at different times, weather, and regions. Its resolution should be sufficient to show short emission peaks. It should also work for extreme events like pest outbreaks and serious storms, especially since those are expected to become more common due to climate change.

A review of the scientific literature has shown that relevant factors for models of biogenic emissions from boreal forests include temperature, light intensity, seasonal factors, the effects of foreseeable damage to trees, and the effect of rainfall, whereas an effect of air pollution is more ambiguous. Also, models 
should use time intervals shorter than a month, especially at bud break. Furthermore, the temperature dependence varies sufficiently to motivate using specific values for the ecosystems examined.

It is clear that more research needs to be done on biogenic monoterpene emissions. Some areas I find to be of particular interest are:

- the sensitivity of northern boreal species to herbivory and pest outbreaks (the quantitative and qualitative differences between emissions from healthy trees and trees with various levels of damage);

- latitudinal and longitudinal variation in the boreal zone (are differences due to climate, soil, genetically different strands, or other factors?)

Experiments should include both measurements using branch enclosure and measurements in ambient air. Enclosure experiments are more precise, as they give information about emissions from a certain part of a certain plant. Measurements in ambient air are needed to test the models, and also to provide a solid empirical basis - including effects from herbivory and rain and other factors that may be excluded from detection in enclosure experiments. The results when measuring in ambient air are also affected by emissions from other vegetation and from the forest floor, which is not the case for enclosure experiments.

\section{References}

[1] Rinne J., Tuovinen J.P., Laurila T., Hakola H., Aurela M. \& Hypen H. Measurements of hydrocarbon fluxes by a gradient method above a northern boreal forest. Agricultural and Forest Meteorology, 102:25-37, 2000 .

[2] Geron C.D., Guenther A.B. \& Pierce T.E. An Improved Model for Estimating Emissions of Volatile Organic-Compounds from Forests in the Eastern United-States. Journal of Geophysical Research-Atmospheres, 99:12773-12791, 1994.

[3] Guenther A.B., Zimmerman P.R., Harley P.C., Monson R.K. \& Fall R. Isoprene and Monoterpene Emission Rate Variability - Model Evaluations and Sensitivity Analyses. Journal of Geophysical Research-Atmospheres, 98:12609-12617, 1993.

[4] Guenther A., Hewitt C.N., Erickson D., Fall R., Geron C., Graedel T., Harley P., Klinger L., Lerdau M., McKay W.A., Pierce T., Scholes B., Steinbrecher R., Tallamraju R., Taylor J. \& Zimmerman P. A GlobalModel of Natural Volatile Organic-Compound Emissions. Journal of Geophysical Research-Atmospheres, 100:8873-8892, 1995.

[5] Guenther A. Seasonal and spatial variations in natural volatile organic compound emissions. Ecological applications, 7:34-45, 1997.

[6] Lindfors V., Laurila T., Hakola H., Steinbrecher R. \& Rinne J. Modeling speciated terpenoid emissions from the European boreal forest. Atmospheric Environment, 34:4983-4996, 2000.

[7] Hakola H., Rinne J. \& Laurila T.: The VOC Emission Rates of Boreal Deciduous Trees. In Biogenic VOC emissions and photochemistry in the 
boreal regions of Europe-BIOREP Air pollution research report. Lindfors V., Ed. Luxemburg, European Commission, 1999, p. 21-28

[8] Johansson C. \& Janson R.W. Diurnal Cycle of O-3 and Monoterpenes in a Coniferous Forest - Importance of Atmospheric Stability, Surface Exchange, and Chemistry. Journal of Geophysical Research-Atmospheres, 98:5121-5133, 1993.

[9] Spanke J., Rannik U., Forkel R., Nigge W. \& Hoffmann T. Emission fluxes and atmospheric degradation of monoterpenes above a boreal forest: field measurements and modelling. Tellus Series B-Chemical and Physical Meteorology, 53:406-422, 2001.

[10] Fuentes J.D., Wang D., Neumann H.H., Gillespie T.J., DenHartog G. \& Dann T.F. Ambient biogenic hydrocarbons and isoprene emissions from a mixed deciduous forest. Journal of Atmospheric Chemistry, 25:67-95, 1996.

[11] Janson R.W. Monoterpene Emissions from Scots Pine and Norwegian Spruce. Journal of Geophysical Research-Atmospheres, 98:2839-2850, 1993.

[12] Steinbrecher R., Hauff K., Hakola H. \& Rössler J. A revised parameterisation for emission modelling of isoprenoids for boreal plants. Biogenic VOC emissions and photochemistry in the boreal regions of Europe-BIOREP Laurila T. \& Lindfors V., Eds., European Commission: Luxemburg, p. 29-43, 1999.

[13] Lerdau M., Litvak M. \& Monson R. Plant-Chemical Defense Monoterpenes and the Growth-Differentiation Balance Hypothesis. Trends in Ecology \& Evolution, 9:58-61, 1994.

[14] Lerdau M., Matson P., Fall R. \& Monson R. Ecological Controls over Monoterpene Emissions from Douglas-Fir (Pseudotsuga-Menziesii). Ecology, 76:2640-2647, 1995.

[15] Hakola H., Rinne J. \& Laurila T. The hydrocarbon emission rates of tealeafed willow (Salix phylicifolia), silver birch (Betula pendula) and European aspen (Populus tremula). Atmospheric Environment, 32:18251833, 1998.

[16] Lewinsohn E., Gijzen M. \& Croteau R. Defense-Mechanisms of Conifers Differences in Constitutive and Wound-Induced Monoterpene Biosynthesis among Species. Plant Physiology, 96:44-49, 1991.

[17] Litvak M.E., Madronich S. \& Monson R.K. Herbivore-induced monoterpene emissions from coniferous forests: Potential impact on local tropospheric chemistry. Ecological Applications, 9:1147-1159, 1999.

[18] Hakola H., Tarvainen V., Back J., Ranta H., Bonn B., Rinne J. \& Kulmala M. Seasonal variation of mono- and sesquiterpene emission rates of Scots pine. Biogeosciences, 3:93-101, 2006.

[19] Guenther A., Zimmerman P. \& Wildermuth M. Natural Volatile OrganicCompound Emission Rate Estimates for United-States Woodland Landscapes. Atmospheric Environment, 28:1197-1210, 1994.

[20] Heiden A.C., Hoffmann T., Kahl J., Kley D., Klockow D., Langebartels C., Mehlhorn H., Sandermann H., Schraudner M., Schuh G. \& Wildt J. 
Emission of volatile organic compounds from ozone-exposed plants. Ecological Applications, 9:1160-1167, 1999.

[21] Juttner F. Changes of Monoterpene Concentrations in Needles of PollutionInjured Picea-Abies Exhibiting Montane Yellowing. Physiologia Plantarum, 72:48-56, 1988.

[22] Lindskog A. \& Potter A. Terpene Emission and Ozone Stress. Chemosphere, 30:1171-1181, 1995.

[23] Janson R.W., De Serves C. \& Romero R. Emission of isoprene and carbonyl compounds from a boreal forest and wetland in Sweden. Agricultural and Forest Meteorology, 98-9:671-681, 1999.

[24] Rinne J., Hakola H., Laurila T. \& Rannik U. Canopy scale monoterpene emissions of Pinus sylvestris dominated forests. Atmospheric Environment, 34:1099-1107, 2000.

[25] Petersson G. High Ambient Concentrations of Monoterpenes in a Scandinavian Pine Forest. Atmospheric Environment, 22:2617-2619, 1988.

[26] Janson R.W. Monoterpene Concentrations in and above a Forest of Scots Pine. Journal of Atmospheric Chemistry, 14:385-394, 1992.

[27] Strömvall A. \& Petersson G. Conifer monoterpenes emitted to air by logging operations. Scandinavian Journal Forest Research, 6:253-258, 1991.

[28] Schade G.W., Goldstein A.H. \& Lamanna M.S. Are monoterpene emissions influenced by humidity? Geophysical Research Letters, 26:2187-2190, 1999.

[29] Schmid C., Steinbrecher R. \& Ziegler H. Partition-Coefficients of Plant Cuticles for Monoterpenes. Trees-Structure and Function, 6:32-36, 1992.

[30] Janson R. \& de Serves C. Acetone and monoterpene emissions from the boreal forest in northern Europe. Atmospheric Environment, 35:4629-4637, 2001. 